\title{
Identifikasi Genetik Hasil Grafting Tanaman Durian (Durio zibethinus Murr.) Lokal Menggunakan 8 Primer
}

\author{
Genetic Identification of Plant Grafting Results Durian (Durio zibethinus Murr.) Local Using 8 \\ Primer
}

\author{
Hanif Fatur Rohman"1, Maria 'Azizah' \\ ${ }^{1}$ Program Studi Produksi Tanaman Hortikultura, Jurusan Produksi Pertanian, Politeknik Negeri Jember \\ ${ }^{2}$ Program Studi Teknik Produksi Benih, Jurusan Produksi Pertanian, Politeknik Negeri Jember \\ haniffaturrohman@polije.ac.id
}

\begin{abstract}
ABSTRAK
Okulasi merupakan teknik perbanyakan vegetatif yang digunakan untuk mempertahankan karakter unggul durian dari batang atas dan batang bawah. Identifikasi genetik merupakan faktor utama untuk mengetahui apakah tanaman hasil perbanyakan okulasi memiliki karakter utama dari tanaman induknya. Penelitian ini bertujuan untuk mengumpulkan informasi tentang keragaman genetik bibit durian dari metode okulasi dan mendapatkan informasi primer terbaik yang dapat digunakan untuk mengidentifikasi genetik durian. Penelitian ini dilakukan di Laboratorium Bioteknologi Fakultas Pertanian Universitas Brawijaya, Malang. Delapan primer yang digunakan adalah OPAI-15, OPB-08, OPAB-14, OPF-13, OPB-10, OPC-05, OPH-15, OPC-08 untuk identifikasi 6 sampel ( 2 induk untuk batang atas dan batang bawah) dan 4 sampel dari bibit okulasi. Hasil penelitian menunjukkan dari 6 sampel dan 8 primer yang digunakan untuk identifikasi, sebagian besar sampel dari perbanyakan okulasi menunjukkan karakteristik batang atas daripada batang bawah. Hasil penelitian juga menunjukkan bahwa ke-8 primer dari penelitian ini dapat digunakan untuk mengidentifikasi DNA tanaman durian.
\end{abstract}

Kata kunci: perbanyakan okulasi, okulasi durian, primer durian, DNA durian.

\begin{abstract}
Grafting is vegetatif propagation techniques that use to maintain superior characters of durian from scion and rootstock. Genethic identification is the main factor to know if the plant from grafting propagation has the main character from the parent plant. This research aimed to collect information about genetic diversity durian seedling from grafting methode and get information the best primer that can be used for identificating durian genethic. This research was was conducted at Laboratorium Bioteknologi Fakultas Pertanian Universitas Brawijaya, Malang. Eight primer that used were OPAI-15, OPB-08, OPAB-14, OPF-13, OPB-10, OPC-05, OPH-15, OPC08 for identificating 6 sample (2 parent for scion and rootstock) and 4 sample from grafting seedling. The result shown from 6 sample and 8 primer that used for identificating, majority of the sample from grafting propagation showing scion characteristic rather than rootstock characteristic. The result also shown that all 8 primer from this research can used for identificating DNA of durian plant.
\end{abstract}

Keyword: grafting propagation, durian grafting, durian primer, durian DNA.

\section{OPEN ACCESS}




\section{Introduction}

Perbanyakan vegetatif menggunakan metode grafting mempunyai beberapa tujuan yang mungkin tidak ada pada metode perbanyakan vegetatif yang lainnya. Perbanyakan melalui metode grafting ialah bertujuan untuk memperbaiki kualitas dan kuantitas tanaman, mengatur proporsi tanaman agar memberikan hasil yang lebih baik, peremajaan tanaman, membuat tanaman tahan hama dan penyakit, mempercepat kematangan reproduktif, dan untuk mendapatkan bentuk pertumbuhan khusus pada tanaman.

Prastowo et al. (2006) menyatakan bahwa dengan menggabungkan dua tanaman menjadi satu, hal yang harus diperhatikan adalah hubungan batang bawah dengan batang atas, kecermatan dalam melakukan grafting dan kondisi faktor lingkungan. Semakin dekat hubungan kekeluargaan antara stock dengan scion akan semakin meningkatkan tingkat keberhasilan grafting yang dilakuan. Semakin jauh hubungan kekeluargaan keduanya, tingkat inkompatibilitas semaking tinggi sehingga proses grafting menjadi gagal. Kecermatan dalam melakukan grafting mempengaruhi penyatuan floem dan xylem batang atas dan batang bawah. Kondisi faktor lingkungan yang berpengaruh pada tingkat keberhasilan grafting adalah suhu dan kelembaban. Pembentukan jaringan penutup luka (kalus) sangat dipengaruhi oleh suhu. Kelembaban yang terlalu tingi akan meningkatkan potensi adanya serangan patogen pada luka bekas grafting.

Teknik modern bioteknologi seperti pengujian secara biomolekuler (DNA, protein, enzim) tidak hanya dapat dimanfaatkan pada perbanyakan benih dan pemuliaan tanaman, tetapi juga dapat diterapkan untuk mengevaluasi kemurnian dan keragaman genetik. Salah satu marka yang digunakan untuk menguji kemurnian genetik adalah marka mikrosatelit atau marka SSR (Simple Sequence Repeats). Marka SSR memiliki beberapa keunggulan, di antaranya memiliki tingkat polimorfisme tinggi, bersifat kodominan, memiliki akurasi tinggi dan terdapat berlimpah di genom. Menurut Blair et al. (1999), marka SSR sering digunakan pada analisis berbasis molekuler. Marka ini juga telah banyak digunakan secara masif pada berbagai studi keragaman genetik, verifikasi serta identifikasi varietas tanaman (Moeljopawiro, 2007) dan digunakan untuk uji kemurnian benih pada tanaman padi hibrida (Liu et al. 2007; Tamilkumar et al. 2009; Xin et al. 2005). Identifikasi tentang kebenaran suatu genotipe tanaman menggunakan marka yang tidak terpaut adalah salah satu metode yang bisa digunakan dalam menilai kemurnian benih hibrida serta satu penanda yang polimorfik sudah dapat dikatakan cukup untuk menguji kemurnian benih (Yashitola et al. 2002). Penggunaan marka SSR telah dilakukan untuk identifikasi variasi genetik tanaman durian (Sales, 2015), Santoso et al., 2017) dan Siew et al. (2018).

\section{Method}

Bahan yang digunakan pada penelitian ini ialah 2 sampel tetua yakni tetua batang bawah dan tetua batang atas, kemudian 4 sampel tanaman hasil grafting. Primer yang digunakan pada penelitian ini ialah, OPAI-15 (kode A), OPB-08 (kode B), OPAB-14 (kode C), OPF-13 (kode D), OPB-10 (kode E), OPC-05 (kode F), OPH-15 (kode G) dan OPC-08 (kode H). Analisis berdasar marka mikrosatelit dilakukan dengan tahap pertama yaitu melakukan ekstraksi serta isolasi DNA yang di ambil dari daun durian dengan menggunakan metode CTAB (Murray and Thompson 1980). Daun durian diambil dengan berat $5 \mathrm{~g}$ dari tiap tanaman sampel. Setelah DNA terisolasi, kemudian dilakukan pengujian kualitas dan kuantitas DNA dengan menggunakan spektrofotometer. Untuk tiap reaksi dengan menggunakan PCR diambil $3 \mu \mathrm{l}$ DNA dari hasil pengenceran yang ditambahkan $2 \mu$ buffer PCR $(10 \mathrm{x}), 2,4 \mu \mathrm{MgCl} 2(25 \mathrm{mM})$, $0,4 \mu$ dNTPs mix (10 mM), 0,2 $\mu$ l primer $\mathrm{R}$ (10 pmol), $0.2 \mu l$ primer $F(10$ pmol $), 0,2 \mu 1$ TaqDNA polymerase $(5 \mu / \mu \mathrm{l})$ dan $10,4 \mu \mathrm{lddH} 2 \mathrm{O}$. Profil reaksi PCR yang digunakan adalah $940 \mathrm{o}$ selama 5 menit proses denaturasi awal, 94oC selama 1 menit denaturasi, 53oC selama 30 detik penempelan primer, $72 \mathrm{oC}$ selama 1 menit untuk proses perpanjangan primer, dan $72 \mathrm{oC}$ selama 5 menit untuk proses perpanjangan pada primer tambahan, kemudian siklus diulang 35 kali. Elektroforesis dari hasil alat PCR menggunakan gel agarose 3\% dan buffer TAE. Sampel DNA dari produk PCR dijalankan pada proses 
elektroforesis dengan voltase $87-88$ volt selama 30-45 menit. Proses elektroforesis gel poliakrilamid dengan alat elektroforesis vertikal dengan buffer TBE. Analisis data molekular ditujukan untuk mengetahui tingkat polimorfisme (PolymorphicInformation Content, PIC) serta mengetahui profil karakterisasi pada marka mikrosatelit.

Analisa data molekular dilakukan berdasarkan pada hasil skoring pita DNA yang muncul pada gel. Nilai 1 diberikan jika ada alel dan nilai 0 jika tidak ada alel. Nilai PIC dihitung untuk masing-masing marka mikrosatelit (Smith et al. 1997), yaitu dilakukan dengan menggunakan software online (www.genomics.liv.ac.uk/animal/Pic1.html).

Format data biner dimanfaatkan untuk membuat analisis kluster berdasarkan metode pautan ratarata UPGMA (Unweighted Pair Group Method Arithmatic) menggunakan program NTSYS versi 2.02. Dendogram dikonstruksi untuk delapan galur tetua. Analisa jarak genetik diperoleh dengan formula: $S=1-G S$, di mana $S$ merupakan jarak genetik dan GS merupakan kemiripan genetik.

\section{Discussion}

\subsection{Deteksi marka SSR spesifik}

Tanaman hasil sambung menunjukkan terdapat keragaman DNA tanaman hasil sambungan, dimana keragaman terjadi berdasarkan jumlah maupun pola pitanya. Hasil PCR menunjukkan bahwa DNA yang di uji bisa di visualisasikan dengan baik sehingga memungkinkan untuk dilakukan interpretasi genetik.

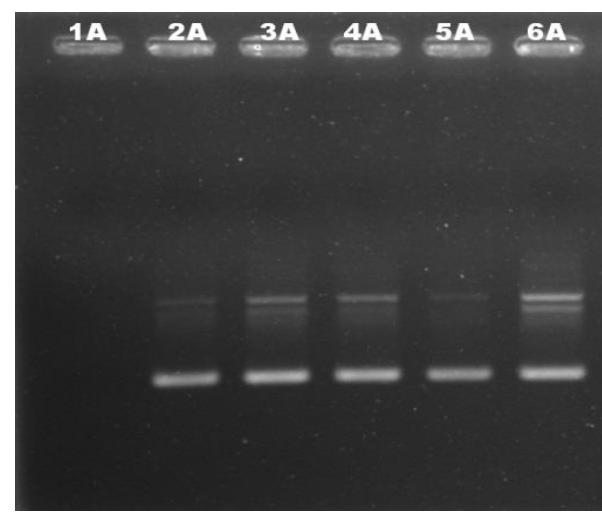

Figure 1. Zimogram pola pita metode PCR dengan menggunakan primer $\mathrm{A}$
Berdasarkan jumlah dan pola pita DNA menggunakan Primer (A) yaitu OPAI-15 dengan susunan basa GACACAGCCC, tetua 1 memiliki pita yang terbaca hanya satu pita sedangkan tetua 2 memiliki 3 pita dan pada sampel hasil sambungan hampir semuanya memiliki pita yang sama dengan tetua 2 dan tidak memiliki pita tetua 1. Hal ini dapat diartikan bahwa hampir semua sampel tanaman hasil sambung akan lebih cenderung memiliki sifat seperti tetua 2 .



Figure 2. Zimogram pola pita metode PCR dengan menggunakan primer $\mathrm{B}$

Berdasarkan jumlah dan pola pita DNA yang menggunakan Primer (B) yaitu OPB-08 dengan susunan basa GTCCACACGG, tetua 1 memiliki pita yang terbaca sebanyak 3 dan tetua 2 juga memiliki 3 pita dengan posisi berbeda, sedangkan pada sampel hasil sambungan hampir semuanya memiliki pita yang sama dengan tetua 2 dan tidak memiliki pita tetua 1 . Hal ini dapat diartikan bahwa hampir semua sampel tanaman hasil sambung akan lebih cenderung memiliki sifat seperti tetua 2 .

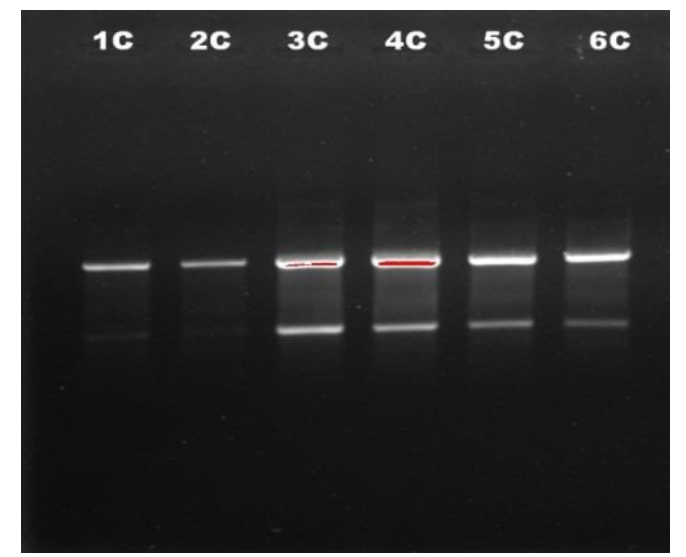

Figure 3. Zimogram pola pita metode PCR dengan menggunakan primer $\mathrm{C}$ 
Gambar 9 menunjukkan jumlah dan pola pita DNA yang menggunakan Primer $(C)$ yaitu OPAB-14 dengan susunan basa AAGTGCGACC, tetua 1 memiliki pita yang terbaca sebanyak 2 dan hampir sama dengan tetua 2 juga memiliki 2 pita dengan posisi yang sama, sedangkan pada sampel hasil sambungan hampir semuanya memiliki pita yang sama dengan tetua 1 dan 2. Hal ini dapat diartikan bahwa hampir semua sampel tanaman hasil sambung akan lebih cenderung memiliki sifat campuran dari tetua 1 dan tetua.



Figure 4. Zimogram pola pita metode PCR dengan menggunakan primer D

Jumlah dan pola pita DNA yang menggunakan Primer (D) yaitu OPF-13 dengan susunan basa GGCTGCAGAA menunjukkan sampel tetua 1 memiliki pita yang terbaca sebanyak 1 dan tetua 2 memiliki 2 pita dengan posisi yang berbeda seperti pada Gambar 10 . Sedangkan pada sampel hasil sambungan dengan kode 3D memiliki pita yang sama dengan tetua 2 saja dan pada sampel hasil sambungan yang memiliki pita campuran atau pita tersendiri.

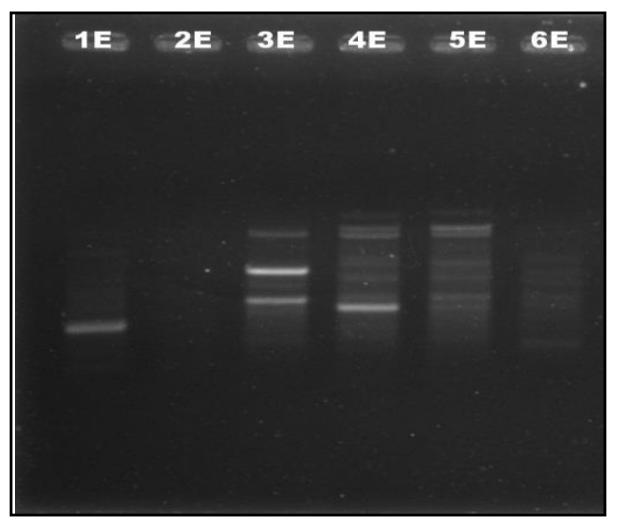

Figure 5. Zimogram pola pita metode PCR dengan menggunakan primer $\mathrm{E}$
Hasil analisis DNA menggunakan metode PCR dengan Primer (E) yaitu OPB-10 dengan susunan basa CTGCTGGGAC, tetua 1 memiliki pita yang terbaca dua pita sedangkan tetua 2 memiliki 1 pita terbaca. Pada sampel hasil sambungan hampir semuanya memiliki pita yang berbeda dengan sampel tetua baik 1 ataupun 2 dan menunjukkan pola pita tersendiri.

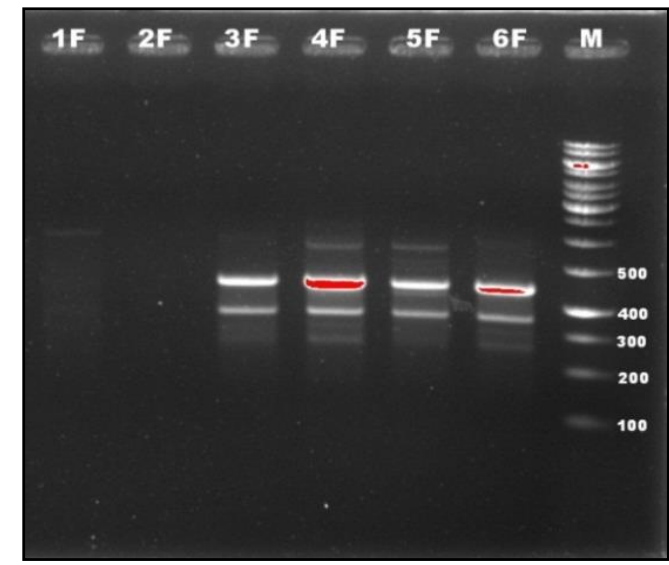

Figure 6. Zimogram pola pita metode PCR dengan menggunakan primer $\mathrm{F}$

Berdasarkan jumlah dan pola pita DNA yang menggunakan Primer $(\mathrm{F})$ yaitu OPC-05 dengan susunan basa GATGACCGCC, tetua 1 memiliki 3 pita yang terbaca dan tetua 2 juga memiliki 1 pita dengan posisi yang hampir sama dengan pita salah satu pita tetua 1 . Pada sampel hasil sambungan hampir semuanya memiliki pita yang sama dengan tetua 1 dan tetua 2 serta memiliki pola pita tersendiri.

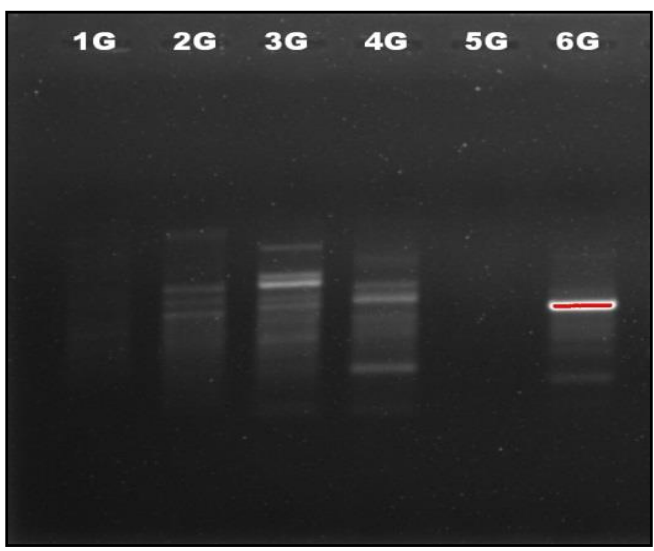

Figure 7. Zimogram pola pita metode PCR dengan menggunakan primer $G$

Hasil analisis PCR dan zimogram menunjukkan jumlah dan pola pita DNA yang menggunakan Primer $(\mathrm{G})$ yaitu OPH-15 dengan 
susunan basa AATGGCGCAG, tetua 1 memiliki 1 pita yang terbaca dan tetua 2 memiliki 3 pita dengan posisi yang berbeda dengan tetua 1. Pada sampel hasil sambungan pada hasil sample kode $3 \mathrm{G}$ memiliki 2 pita yang sama dengan tetua 1 dan tetua 2. Sampel hasil sambungan lain memiliki pola pita yang berbeda dengan tetua 1 maupun tetua 2 .

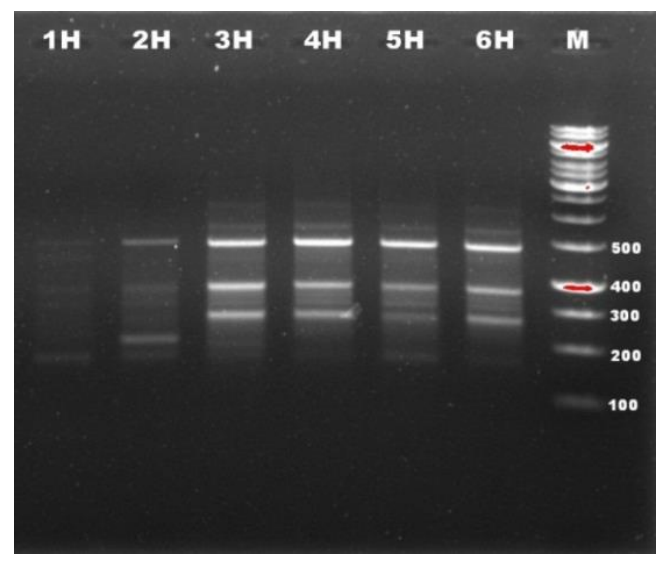

Figure 8. Zimogram pola pita metode PCR dengan menggunakan primer $\mathrm{H}$

Hasil analisis DNA menggunakan metode PCR dengan Primer $(\mathrm{H})$ yaitu OPC-08 dengan susunan basa TGGACCGGTG, tetua 1 memiliki pita yang terbaca 2 pita sedangkan tetua 2 memiliki 4 pita terbaca dengan posisi yang berbeda. Pada sampel hasil sambungan dengan kode $5 \mathrm{H}$ dan $6 \mathrm{H}$ memiliki 3 pita yang sama dengan sampel tetua baik 1 maupun tetua 2 . Sedangkan sampel hasil sambungan kode $3 \mathrm{H}$ dan $4 \mathrm{H}$ memiliki 2 pita yang sama dengan tetua 2 .

\subsection{Jarak Genetik}

Hasil dendogram (Gambar 9) menunjukkan bahwa terdapat tiga kelompok besar tingkat kemiripan yakni yang pertama tetua 1 memiliki kemiripan dengan sampel 1 dengan kemiripan genetik sebesar 0,42. Pada kelompok kedua tetua 2 memiliki kemiripan genetik sebesar 0.72 dengan sampel 2,3 dan 4. Pada sampel 2 dan sampel 3 memiliki kemiripan genetik sebesar 0.88 dan sampel 4 memiliki kemiripan genetik sebesar 0,81 . Semakin besar nilai koefisien kemiripan genetik maka semakin besar kemiripan genetiknya. Dominasi batang atas terhadap tanaman hasil sambung menyebabkan sebagian besar tanaman hasil sambung cenderung mewarisi genetik dari tetua batang atas. Hal ini sama dengan penelitian Surbakti (2004) yang menyatakan bahwa hasil sambungan batang bawah ubi kayu biasa yang disambung dengan ubi kayu racun di dapatkan bahwa sifat sifat ubi kayu racun lebih dominan seperti pada aspek kandungan karbohidrat dan umur panen yang lebih cenderung mirip dengan sifat ubi kayu racun.

Menentukan prediksi heterosis dapat menggunakan jarak genetik apabila heterozigositas antar tetua memiliki hubungan yang erat dengan tampilan hibridanya. hubungan antar jarak genetik dan heterosis bergantung pada materi, rancangan penelitian, dan marka molekuler yang digunakan. Pada penelitan ini, perbedaan genetik antara tetua dianalisis dengan marka molekular nonspesifik yang dipilih secara acak. Jarak genetik yang didapatkan berdasarkan lokus acak dapat menyebabkan hasil yang tidak konsisten bila digunakan untuk menganalisis korelasi antara jarak genetik antartetua dengan hetererosis (Zhang et al. 2010). 


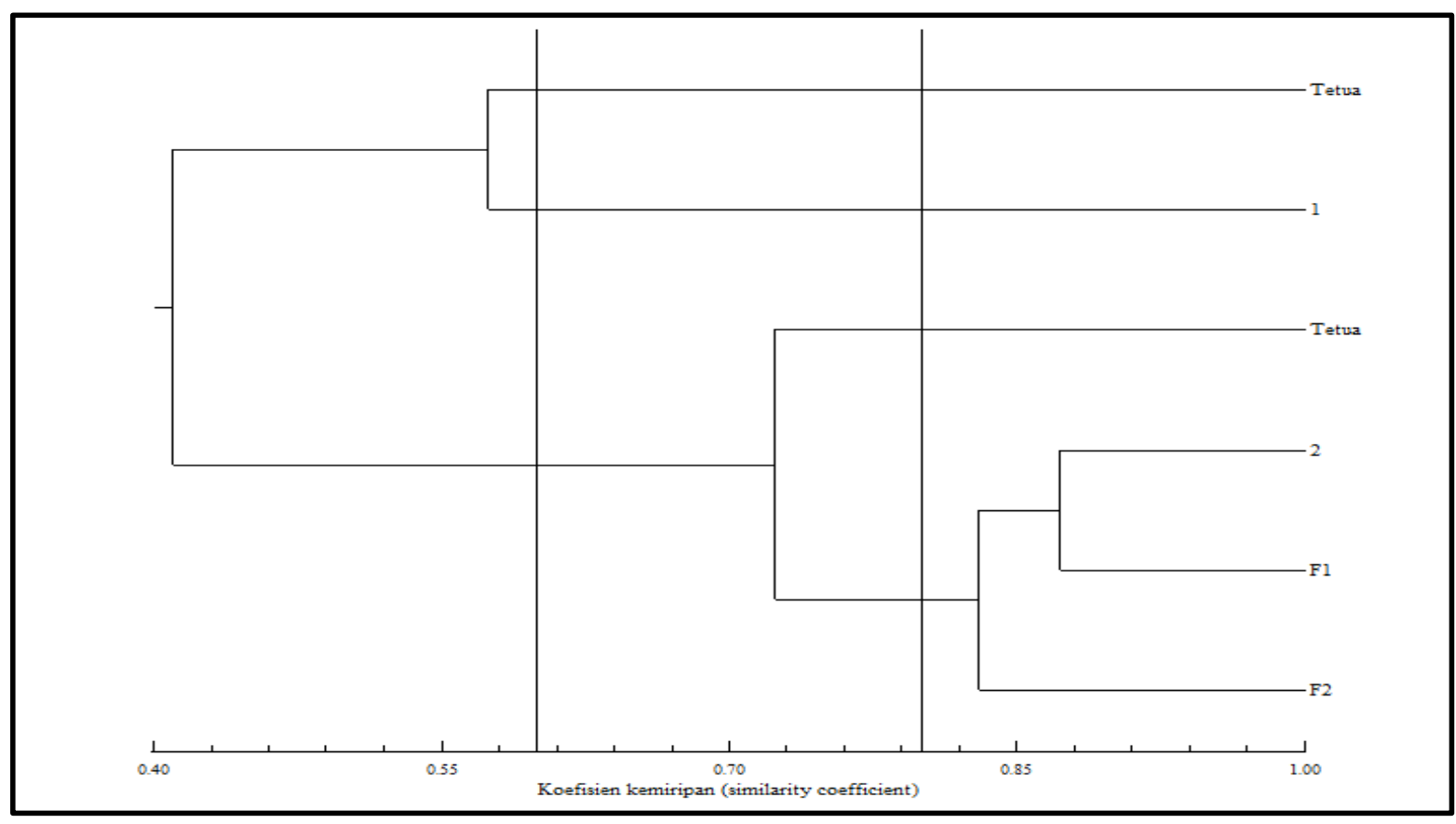

Figure 9. Dendogram analisis UPGMA berdasarkan kemiripan genetik

Aspek genetik pada perbanyakan tanaman menggunakan cara vegetatif berkaitan erat dengan keseragaman serta keragaman pada genetik tanaman yang dibiakkan dengan cara vegetatif. Tanaman yang telah diperbanyak dengan metode vegetatif dimungkinkan mempunyai kemiripan secara genetik karena berasal dari induk yang sama. Teknik perbanyakan ini dapat dilakukan sebagai upaya pelestarian sifat-sifat unggul yang dimiliki oleh tanaman tertentu. Tetapi dengan adanya interaksi genetik ini dapat menyebabkan perubahanperubahan pada morfologi tanaman yang bisa bersifat sementara maupun permanen karena terjadi beberapa perubahan material genetiknya.

\section{Conclusion}

Hasil analisis genetik menunjukkan bahwa masing-masing sampel memiliki kemiripan genetik baik dari tetua batang atas ataupun tetua batang bawah, namun sebagian sampel lebih cenderung mirip dengan tetua batang atas serta memiliki keragaman genetik sendiri. Selain itu, delapan primer yang digunakan dalam penelitian semuanya bisa dipakai untuk identifikasi DNA tanaman durian.

\section{References}

[1] Blair, M.W., O. Panaud, and S.R. McCouch. 1999. Inter-simple sequence repeat (ISSR) amplification for analysis of microsatellite motif frequecy and fingerprinting in rice (Oryzasativa L.) Theor. Appl. Genet. 98: 780-792.

[2] Liu, L.W., Y. Wang, Y.Q. Gong, T.M. Zao, G. Liu, X.Y. Li, and F.M. Yu. 2007. Assessment of genetic purity of tomato (Lycopercicumesculentum L.) hybrid using molecular marker. Scientific Horticulture 115: 7-12.

[3] Meesang, N., S.L. Ranamukhaarachchi, M.J.

[4] Moeljopawiro, S. 2007. Marka mikrosatelit sebagai alternatif uji BUSS dalam perlindungan varietas tanaman padi. Zuriat 18(2):129-138.

[5] Murray, M.G. and W.P. Thompson. 1980. Rapid isolation on high molecular weight DNA. Nucleic Acid Rep. 8:4321-4325.

[6] Prastowo, N., Roshetko, J. M., Maurung, G. E. S., Nugraha, E., Tukan, J. M. dan Harum, F. 2006.Tehnik Pembibitan dan Perbanyakan Vegetatif Tanaman Buah. World Agroforestry Centre (ICRAF) dan Winrock International. Bogor, Indonesia. p. 5-9.

[7] Sales, E.K. 2015. Durian Marker Kit for Durian (Durio zibethinus Murr.) Identity. International Journal of Biological, Food, Veterinary and Agricultural Engineering 9(5): 497-507.

[8] Santoso, P.J., A. Pancoro, S. Suhandono, I.N.P. Aryantha. 2017. Development of Simple-Sequence Repeats Markers from Durian (Durio zibethinus Murr. cultv. Matahari) Genomic Library. Agrivita Journal of Agricultural Science. 39(3): 257-265.

[9] Smith, J.S.C., E.C.L. Chin, H. Shu, O.S. Smith, S.J. Wall, M.L. Senior, S.E. Mitchel, S. Kresovich, and J. Ziegle. 1997. An evaluation of the utility of SSR loci 
as molecular markers in maize (Zea mays L.): comparision with data from RFLPS and pedigree.Theor. Appl. Genet. 95:163-173.

[10] Siew, G.Y., W.L. Ng, S.W. Tan, N.B. Alitheen, S.G. Tan, S.K. Yeap. 2018. Genetic variation and DNA fingerprinting of durian types in Malaysia using simple sequence repeat (SSR) markers. PeerJ 6:1-18

[11] Surbakti, R. 2004. Pengaruh Manipulasi Genetika dengan Metode Sambung Pucuk antara Ubi Kayu Racun dan Ubi Kayu biasa (Manihot utilisima) terhadap Peninngkatan Kadar Karbohidrat dan Produksi Umbi yang dihasilkan. J. Sains. Kimia. 8(1):15-18.

[12] Tamilkumar, P., R. Jerlin, N. Senthil, K.N. Ganesan, R.J. Jeevan, and Raveendran. 2009. Fingerprinting of rice hybrid and their parental lines using microsatelite marker and their utilization in genetic purity assessment of hybrid rice. Rice Journal of Seed Science 2(3):40-47.

[13] Xin, Y., Z. Zhang, Y. Xiong, and L. Yuan. 2005. Identification and purity of super hybrid rice with SSR molekular marker. J. Rice Science 12(1):7-12.

[14] Yashitola, J., T. Thirumurgan, R.M. Sudaram, M.K. Naseerullah, M.S.Ramesha, N.P. Sarma, and R.V. Sonti. 2002. Assessment of purity of rice hybrid using microsatellite and STS marker. Crop Sci. 42:13691373.

[15] Zhang, T,. X. Ni, Jiang K., H. Deng, Q. He, Q. Yang, L. Yang, X. Wang,Y. Cao, and J. Zheng. 2010. Relationship between heterosis and parental genetic distance based on molecular markers for functional genes related to yield traits in rice. J. Rice Sci. 17(4):288-295. 